Review Article

\title{
Cyanobacterial nitrogenases: phylogenetic diversity, regulation and functional predictions
}

Alberto A. Esteves-Ferreira ${ }^{1,2}$, João Henrique Frota Cavalcanti ${ }^{1,2}$, Marcelo Gomes Marçal Vieira Vaz ${ }^{1,2}$, Luna V. Alvarenga ${ }^{1,2}$, Adriano Nunes-Nesi ${ }^{1,2}$ and Wagner L. Araújo ${ }^{1,2}$

${ }^{1}$ Departamento de Biologia Vegetal, Universidade Federal de Viçosa, Viçosa, MG, Brazil.

${ }^{2}$ Max-Planck-partner group at the Departamento de Biologia Vegetal, Universidade Federal de Viçosa, Viçosa, MG, Brazil.

\begin{abstract}
Cyanobacteria is a remarkable group of prokaryotic photosynthetic microorganisms, with several genera capable of fixing atmospheric nitrogen $\left(\mathrm{N}_{2}\right)$ and presenting a wide range of morphologies. Although the nitrogenase complex is not present in all cyanobacterial taxa, it is spread across several cyanobacterial strains. The nitrogenase complex has also a high theoretical potential for biofuel production, since $\mathrm{H}_{2}$ is a by-product produced during $\mathrm{N}_{2}$ fixation. In this review we discuss the significance of a relatively wide variety of cell morphologies and metabolic strategies that allow spatial and temporal separation of $\mathrm{N}_{2}$ fixation from photosynthesis in cyanobacteria. Phylogenetic reconstructions based on 16S rRNA and nifD gene sequences shed light on the evolutionary history of the two genes. Our results demonstrated that ( $I$ ) sequences of genes involved in nitrogen fixation (nifD) from several morphologically distinct strains of cyanobacteria are grouped in similarity with their morphology classification and phylogeny, and (ii) nifD genes from heterocytous strains share a common ancestor. By using this data we also discuss the evolutionary importance of processes such as horizontal gene transfer and genetic duplication for nitrogenase evolution and diversification. Finally, we discuss the importance of $\mathrm{H}_{2}$ synthesis in cyanobacteria, as well as strategies and challenges to improve cyanobacterial $\mathrm{H}_{2}$ production.
\end{abstract}

Keywords: Cyanobacteria, evolution, hydrogen, nitrogen fixation, molecular phylogeny.

Received: February 29, 2016; Accepted: December 21, 2016.

\section{Introduction}

Cyanobacteria is a biochemically and morphologically diverse group of gram-negative bacteria capable of perform oxygenic photosynthesis (Figure 1). These microorganisms are observed in fresh water, marine and terrestrial habitats, being the major primary producers in these ecosystems (Hess, 2011). Fossil records indicate that cyanobacteria have been extant for at least 2.5 billion years (Knoll, 2008). Additionally, it is likely that the ancestors of cyanobacteria played a key role in the formation of atmospheric oxygen $\left(\mathrm{O}_{2}\right)$ (Hackenberg et al., 2011) and are also believed to have evolved into the present-day chloroplasts of green algae and plants (Koonin, 2010; Keeling, 2013). Cyanobacterial metabolic plasticity appears to have permitted these organisms to withstand the challenges of evolutionary environmental changes and has enabled them to survive and colonize diverse habitats (Steinhauser et al., 2012). Indeed, these organisms exhibit enormous diversity

Send correspondence to Wagner L. Araújo. Departamento de Biologia Vegetal, Universidade Federal de Viçosa, 36570-900, Viçosa, MG, Brazil. E-mail: wlaraujo@ufv.br in terms of their habitats, morphology, physiology, and metabolism (Beck et al., 2012). These microorganisms display a relatively wide variety of morphologies, such as unicellular, non-heterocytous and heterocytous filamentous strains with the latter showing different types of cells (heterocytes and akinetes) (Schirrmeister et al., 2013) (Figure 1a-h). Heterocytous strains are able to form differentiated cells, specialised in nitrogen $\left(\mathrm{N}_{2}\right)$ fixation, the heterocytes, and spore-like resting cells, the akinetes (Figure 1f-h). However, a number of unicellular (Figure 1a-b) and non-heterocytous (Figure 1c-e) strains are also able to perform $\mathrm{N}_{2}$ fixation under certain conditions, despite the absence of specialised cells (Berman-Frank et al., 2003).

Occurrence of nitrogen fixation (nif) gene clusters has been reported in several organisms. However, all known $\mathrm{N}_{2}$-fixing organisms are prokaryotes and thus the ability to fix $\mathrm{N}_{2}$ is widely, though paraphyletically, distributed across bacterial and archaeal domains (Staley and Reysenbach, 2002; Raymond et al., 2004). Additionally, nif genes have been identified in 21 out of the 44 sequenced cyanobacterial genomes thus far, including terrestrial and marine strains (Boyd and Peters, 2013). They are organized in dis- 

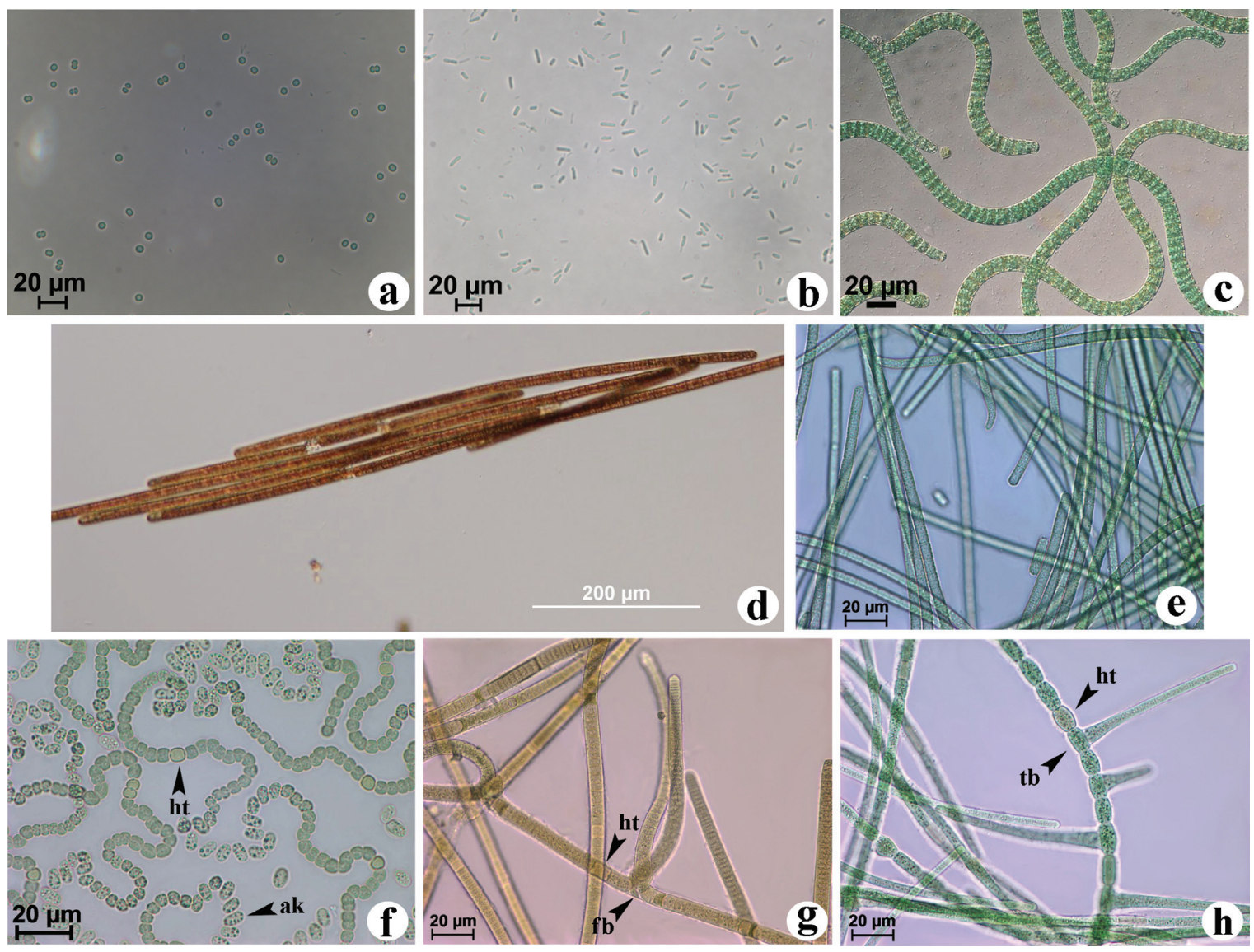

Figure 1 - Natural morphological variation within cyanobacterial genera. Unicellular strains: (a) Synechocystis sp. PCC6803 and (b) Synechococcus elongatus PCC4972. Non-heterocytous strains: (c) Arthrospira maxima, (d) Trichodesmium sp. and (e) Phormidium sp. CCM-UFV034. False branching or non-branching heterocytous strains: (f) Nostoc sp. CCM-UFV028 and (g) Brasilonema octagenarum CCM-UFVE1. True-branching heterocytous strain: (h) Stigonema sp. CCM-UFV036. Synechocystis sp. (a) and Arthrospira maxima (c) are unable to perform $\mathrm{N}_{2}$ fixation, whereas the strains shown in $\mathrm{b}$ and e present a temporal separation of metabolism: photosynthetic $\mathrm{CO}_{2}$ fixation is performed in the light while $\mathrm{N}_{2}$ fixation occurs during darkness. Trichodesmium sp. (d) is the unique non-heterocytous cyanobacterium that shown $\mathrm{N}_{2}$ fixation under light conditions. Conversely, in other strains (f, $\mathrm{g}$, and $\mathrm{h}$ ), there is a spatial separation of metabolism, with $\mathrm{N}_{2}$ fixation occurring in heterocytes (ht). Abbreviations: (ak) akinetes; (fb) false branching; (tb) true branching. The picture of Arthrospira maxima (c) was kindly provided by the Culture Collection of Autotrophic Organisms (CCALA), http://ccala.butbn.cas.cz and the picture of Trichodesmium sp. (d) by Prof. Ondøej Práil, Institute of Microbiology, Czech Academy of Sciences, Czech Republic. The other pictures are from strains kept at Collection of Cyanobacteria and Microalgae from Universidade Federal de Viçosa (CCM-UFV).

tinct operons namely nifB-fdxN-nifSU, nifHDK, nifENXW, and nifVZT (Figure 2A). Interestingly, in Anabaena spp. there is an $11-\mathrm{kb}$ excision element in the nifHDK operon, which is removed from the chromosome during the differentiation of vegetative cells to heterocytes, allowing the transcription of the complete operon (Golden and Wiest, 1988; Brusca et al., 1990). Moreover, nifVZT is present in a separate nif gene cluster (Figure 2A) (Pratte and Thiel, 2014). The intrinsic capacity for $\mathrm{N}_{2}$ fixation in cyanobacteria is related only to the nitrogenase enzyme system, with the molybdenum nitrogenase (Mo-nitrogenase) being the most studied nitrogenase (Betancourt $e t$ al., 2008) (Figure 2B). This enzymatic complex comprises approximately $10 \%$ of the total cellular protein in many diazotrophs, requesting 16 ATPs per $\mathrm{N}_{2}$ fixed (Simpson and Burris, 1984; Berman-Frank et al., 2003), and catalyzes the synthesis of approximately half of all of the fixed $\mathrm{N}_{2}$ on Earth nowadays (Falkowski, 1997). In addition, ni- trogenase also catalyzes the production of hydrogen $\left(\mathrm{H}_{2}\right)$ as a by-product of $\mathrm{N}_{2}$ fixation (Seefeldt et al., 2009; Bothe et al., 2010). Nitrogenase enzyme consists of two parts: the dinitrogenase, a FeMo-protein encoded by the genes nif $\mathrm{D}$ ( $\alpha$-subunit) and nifK ( $\beta$-subunit), which is organized in a $\alpha 2 \beta 2$ tetramer of $240 \mathrm{kDa}$ associated with two FeMocofactors (FeMo-co) and two P-clusters; and the dinitrogenase reductase, a homodimer $(2 \times 30 \mathrm{kDa})$ with one [4Fe-4S]-cluster (Fe Protein) encoded by nifH (Figure 2B) (Orme-Johnson, 1992; Böhme, 1998).

Although the function of the proteins encoded by the other nif genes in Anabaena variabilis ATCC29413 (a model filamentous heterocytous strain for physiological studies) remains elusive, possible functions were inferred by analysing nif genes already described in other diazotrophic bacteria (Böhme, 1998). NifE and NifN is a heterotetrameric complex similar to NifD and NifK respectively, 


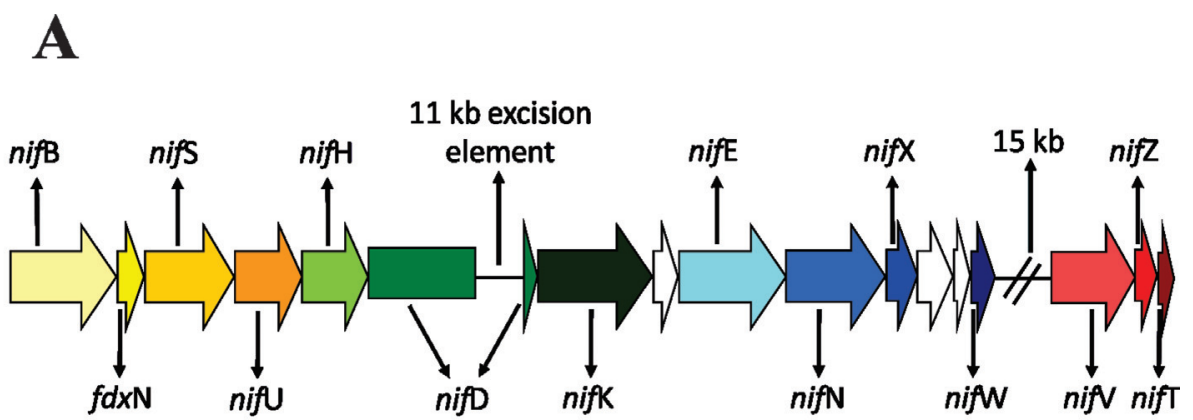

$\underline{1 \mathrm{~kb}}$

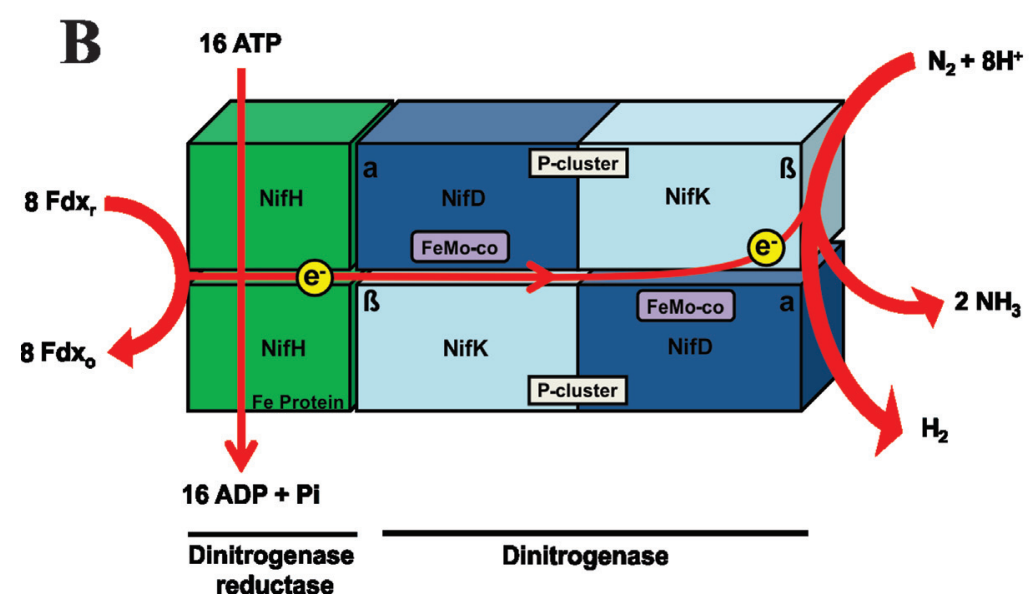

Figure 2 - Nitrogenase gene structure. (A) Map illustrating two of the nif gene clusters present in Anabaena variabilis ATCC29413. The operons are represented using different colours: yellow (nifB-fdxN-nifSU), green (nifHDK), blue (nifENXW) and red (nif $\mathrm{VZT}$ ). White arrows indicate genes which encode proteins with unknown functions. The 11-kb excision element observed in the nifHDK operon is not present in the chromosomes of heterocytes. nif $\mathrm{VZT}$ is part of a second nif gene cluster. (B) Nitrogenase structure and biochemical activity. Dinitrogenase reductase is a homodimer $(2 \times 30 \mathrm{kDa})$ with one $[4 \mathrm{Fe}-4 \mathrm{~S}]$-cluster (Fe protein) encoded by $n i f \mathrm{H}$, whereas dinitrogenase is a FeMo-protein encoded by the genes nif $\mathrm{D}$ ( $\alpha$-subunit) and nifK ( $\beta$-subunit) and organized in a $\alpha 2 \beta 2$ tetramer of $240 \mathrm{kDa}$ associated with two FeMo-cofactors (FeMo-co) and two P-clusters. Notably, there are three types of dinitrogenases normally found in cyanobacterial nitrogenases, which vary depending on the metal content. Thus, type 1 contains molybdenum (Mo), type 2 contains vanadium $(\mathrm{V})$, and type 3 iron $(\mathrm{Fe})$. The reduction of nitrogen $\left(\mathrm{N}_{2}\right)$ to ammonia $\left(\mathrm{NH}_{3}\right)$ requires metabolic energy in the form of ATP, and in this context two ATP molecules are used for each electron transferred from the dinitrogenase reductase to dinitrogenase. Consequently, the reaction requires a total of 16 ATP molecules until the dinitrogenase has accumulated enough electrons to reduce $\mathrm{N}_{2}$ to $\mathrm{NH}_{3}$. In addition, this reaction is accompanied by the reduction of two protons $\left(\mathrm{H}^{+}\right)$to one hydrogen molecule $\left(\mathrm{H}_{2}\right)$.

and seems to act as scaffolds for FeMo-co assembly (Fani et al., 2000). NifV is a homocitrate synthetase which provides homocitrate for the FeMo-co biosynthesis (Zheng et al., 1997; Mayer et al., 2002). NifS and NifU are involved in iron and sulphur mobilization, and in the assembly of [4Fe-4S] clusters (Rubio and Ludden, 2008). Thus, these [4Fe-4S] clusters are transferred to NifB, and converted into NifB-cofactor, a precursor for the biosynthesis of FeMo-co (Curatti et al., 2007). NifX is able to bind precursors of the FeMo-co, being a transient reservoir for these molecules (Hernandez et al., 2007). NifW is not directly involved in the FeMo-protein assembly, but associate with it under aerobic conditions, being part of an $\mathrm{O}_{2}$ protection system (Kim and Burgess, 1996). NifZ is important for P-cluster maturation (Hu et al., 2007) and the function of NifT remains unclear (Thiel and Pratte, 2014).
Cyanobacteria play major environmental and economic roles, including global primary productivity (Paerl, 2012), potential uses in renewable energy, commonly referred to as 'third-generation fuels', (Dismukes et al., 2008; Hu et al., 2008), and are also an immense source of valuable natural products with biotechnological applications (Pulz and Gross, 2004; Rastogi et al., 2010; Wijffels et al., 2013). This photosynthetic group of prokaryotic organisms can therefore be developed as a highly productive microbial cell factory that can harvest solar energy and capture carbon dioxide from the atmosphere, converting it into both biofuels and several useful products (Parmar et al., 2011). The high photosynthesis capabilities of cyanobacteria allow them to convert up to $10 \%$ of the received solar energy into biomass, in comparison with 5-6\% energy conversion registered for $\mathrm{C} 4$ crops such as maize and sugar cane, and 5\% for algae (Parmar et al., 2011; Jones and Mayfield, 
2012; Ogawa and Sonoike, 2015). Accordingly, cyanobacteria are advantageous organisms for use in industrial applications because they exhibit rapid cell growth, have simple nutrient requirements (mainly water, sunlight and $\mathrm{CO}_{2}$ ) (Ruffing, 2011) and are naturally transformable, thus presenting the potential to be genetically engineered (Heidorn et al., 2011; Ruffing, 2011; Wilde and Dienst, 2011). Due to their natural morphological (Figure 1a-h) and physiological diversity coupled with their capacity of growing in a variety of environments, even in areas that are inappropriate for agriculture, there is a growing interest to understand cyanobacterial strains (Machado and Atsumi, 2012). However, despite their promise, different biotechnical, environmental and economic bottlenecks have to be overcome before cyanobacteria can become industrial large scale microorganisms (Parmar et al., 2011; Savage, 2011). One such challenge clearly involves research towards the application of cyanobacteria for the production of alternative biofuel sources, as molecular techniques for metabolic genetic engineering are currently available and in use (Wijffels et al., 2013). Thus, although research towards the application of cyanobacteria for biofuel production has been mainly focused on strains belonging to the genera Synechocystis and Synechococcus, with much smaller additional efforts being carried out in $\mathrm{N}_{2}$-fixing strains such as Anabaena, Nostoc and some Cyanothece, despite nitrogenase being a promising candidate for photobiological hydrogen $\left(\mathrm{H}_{2}\right)$ production.

In this study, we asked whether cyanobacterial nitrogenase complex evolution is congruent with the morphological and 16S rRNA diversity. Due to the higher availability and quality of the nifD nucleotides sequences in comparison to the one for nif $\mathrm{K}$ and nif $\mathrm{H}$, we selected the first gene to perform the phylogenetic analysis. For this purpose, phylogenetic reconstructions based on partial sequences of nifD and 16S rRNA gene sequence were perfomed. The results presented here are a compilation of robust phylogenetic analyses performed by us including a vast number of cyanobacterial strains. Then, we discuss our phylogenetic findings comparing it with previously published data on nitrogenase phylogenetic evolution, placing special attention to nitrogenase and the role of this enzyme during cyanobacterial evolution. Finally, we discuss the regulation of different strategies used by cyanobacteria to avoid nitrogenase inactivation and degradation by $\mathrm{O}_{2}$, providing an update on technologies and molecular tools that have been developed to allow increased cyanobacterial hydrogen production.

\section{Can $\mathrm{N}_{2}$ fixation strategies be associated with cyanobacterial morphology?}

The expression of nif genes is controlled by the carbon-nitrogen $(\mathrm{C} / \mathrm{N})$ balance and cellular redox status in cyanobacteria (Valladares et al., 1999), with 2-oxoglutarate being a signal molecule of the cellular nitrogen levels (Lee et al., 1999; Zhao et al., 2010). Ammonium, as the most reduced inorganic form of nitrogen, is the preferred source of nitrogen for cyanobacteria. Hence, when present in the environment, it represses indirectly the expression of nif genes by blocking the transcription of NtcA, a transcriptional activator associated with global nitrogen control in cyanobacteria (Herrero et al., 2001). Then, in the presence of nitrogen sources other than ammonium, or under nitrogen starvation, NtcA activates the transcription of a set of genes by binding to the target consensus nucleotide sequence GTAN8TAC present in the promoter region (Luque et al., 1994). These genes include not only the nifHDK operon encoding the nitrogenase complex (MuroPastor et al., 2002), but also genes involved in heterocyte development (Flores and Herrero, 2005); mobilization of stored nitrogen (phycobilisome) (Luque et al., 2001), assimilation of ammonium via the GS/GOGAT (glutamine synthetase/glutamine oxoglutarate aminotransferase) cycle (Muro-Pastor et al., 1996; Reyes et al., 1997; VázquezBermúdez et al., 2002), sensing and control of cellular nitrogen homeostatsis by the PII protein (García-Domínguez and Florencio, 1997) and NtcA itself (Alfonso et al., 2001; Paz-Yepes et al., 2003). In strains unable to fix $\mathrm{N}_{2}$, NtcA activates the uptake of nitrogen sources such as nitrate, urea, and ammonium (Suzuki et al., 1995; Valladares et al., 2002; Flores et al., 2005; Paz-Yepes et al., 2007).

As observed for the activity of nitrogenase, it has been demonstrated that levels of nif transcripts and the biosynthesis of different subunities of the nitrogenase complex are very sensitive to $\mathrm{O}_{2}$ (Fay, 1992; Staal et al., 2007; Steunou et al., 2008), most likely to avoid energy losses associated with the degradation of this enzyme under high levels of $\mathrm{O}_{2}$. Thus, to cope with the production of $\mathrm{O}_{2}$ inside their own cells by photosynthesis, which provides energy for all cellular processes, including $\mathrm{N}_{2}$ fixation, cyanobacteria have evolved strategies that protect nitrogenase complex from $\mathrm{O}_{2}$. Many cyanobacterial strains reconcile nitrogenase activity with photosynthesis (Bergman et al., 1997; Berman-Frank et al., 2003) through spatial and/or temporal separation of these two incompatible metabolic processes (Stal, 2008; Flores and Herrero, 2010; Stal et al., 2010).

Many filamentous cyanobacteria solve the issue by cell differentiation. Thus, in heterocytous cyanobacteria, under aerobic growth conditions, $\mathrm{O}_{2}$ evolution and $\mathrm{CO}_{2}$ fixation (photosynthesis) is performed in vegetative cells, whereas nitrogenase catalyses $\mathrm{N}_{2}$-fixation in specialised cells called heterocytes (Figure 1f-h) (Stal, 2008; Cardona et al., 2009; Stal et al., 2010). These specialised cells differentiate from vegetative cells 12 to $20 \mathrm{~h}$ after combined nitrogen sources are removed from the medium, which leads to extensive metabolic changes (Ow et al., 2008). To protect the nitrogenase from $\mathrm{O}_{2}$, the photosystem II (PSII) is largely degraded in heterocytes, and because of that, these 
cells cannot perform the photosynthetic water-splitting reaction, which is associated with an improved respiration rate and the synthesis of a glycolipid layer in the celluar envelope (Murry and Wolk, 1989; Cardona et al., 2009). The synthesis of a bilayered polysaccharide and glycolipid envelope seems to retard the diffusion of gases, which, combined with changes in the photosynthetic apparatus, results in a microoxic environment, allowing nitrogenase activity during the day (Walsby, 1985, 2007). Additionally, these cells are unable to fix $\mathrm{CO}_{2}$ photosynthetically (Stal, 2008). To cope with the absence of energy production, vegetative cells provide photosynthetically fixed carbon to the heterocytes, most likely in the form of carbon exported as sucrose. In turn, the heterocytes provide nitrogen, most likely as glutamine formed via the ammonia generated by $\mathrm{N}_{2}$ fixation and the action of glutamine synthetase (GS) (Curatti et al., 2002; Burnat et al., 2014). This connection to vegetative cells occurs through a pore which is equipped with microplasmodesma (Böhme, 1998). Additionally, the levels of GS in heterocytes are very high to prevent the inhibition of nitrogenase by ammonium accumulation (Renström-Keliner et al., 1990). Some heterocytous cyanobacteria, such as Anabaena variabilis ATCC29413, are able to synthesise a different Mo-dependent nitrogenase (Nif2) in vegetative cells (Thiel et al., 1995; Thiel and Pratte, 2001). This enzyme is synthesized only under anoxic conditions, shortly after nitrogen depletion, and long before heterocytes form (Schrautemeier et al., 1995; Thiel et al., 1997). Additionally, Nif2 is also found in vegetative cells of non-heterocytous species (Berman-Frank et al., 2003). Curiously, the gene $f d x H 2$, that is part of the nif 2 cluster in A. variabilis ATCC29413, has more residues in common with the sequence of $f d x H$ of the non-heterocytous filamentous cyanobacteria Plectonema boryanum PCC73110 (Schrautemeier et al., 1995). Indeed, it seems clear that there is a relation among nif 2 cluster and nif sequences cluster in filamentous non-heterocytous strains (Oscillatoriales and Pseudanabaenales orders), and it is reasonable to assume that the divergence of it might have occurred prior to the heterocytous cell appearance.

Although many unicellular and non-heterocytous cyanobacterial strains can fix $\mathrm{N}_{2}$ (Figure 1a-e), the vast majority of them can do this only under anaerobic conditions or, rather, under conditions of decreased $\mathrm{O}_{2}$ tension. It has been demonstrated that to fix $\mathrm{N}_{2}$, several of these strains have evolved a temporal separation of these two incompatible reactions, with photosynthetic $\mathrm{CO}_{2}$ fixation being performed in the light and $\mathrm{N}_{2}$ fixation occurring in darkness (Berman-Frank et al., 2007). Amongst these strains, the non-heterocytous filamentous strains Symploca and Lyngbya majuscula and the unicellular strains Gloeothece and Cyanothece are worthy of note (Colón-López et al., 1997; Stal, 2008). In these types of cyanobacteria, nitrogenase is typically present in all cells, and a high nitrogenase activity coincides with high respiration rates, with a time difference of $12 \mathrm{~h}$ from the peak of photosynthetic activity (Berman-Frank et al., 2003). This pattern is also reflected at the transcriptional level, being observed under either continuous light or darkness, implicating circadian control of these processes (Colón-López et al., 1997; Steunou et al., 2006). In Synechococcus an accumulation of $n t c \mathrm{~A}$ transcripts is observed during the day, indicating an insufficiency of fixed $\mathrm{N}_{2}$ and promoting an accumulation of nif transcripts during the evening, when the net oxygen evolution is low or negative (Steunou et al., 2008).

One conspicuous feature is observed for the marine non-heterocytous filamentous genus Trichodesmium (Figure 1d) (Lin et al., 1998). Unlike all other non-heterocytous species of cyanobacteria, in this species, the enzyme nitrogenase is compartmentalised in a fraction of cells called diazocytes (typically between 10 and $20 \%$ of the total number of cells) that are often arranged consecutively along the trichome (Lin et al., 1998; Berman-Frank et al., 2001; Rodriguez and Ho, 2014). Diazocytes are structurally different from vegetative cell, since they have a less-granulated aspect. This appearance is related with a decrease in cyanophycin, aerotopes and polyphosphate granules, and an increase in the internal membranes (Fredriksson and Bergman, 1997). These structural changes and the expression of nitrogenase happens in an interval between 8 and 27 hours (Sandh et al., 2012). However, different from heterocytes, diazocytes remained able to perform cell division (Fredriksson and Bergman, 1995). Immunological analyses have revealed the presence of nitrogenase only in diazocytes (Berman-Frank et al., 2001), although few studies propose that almost all cells of Trichodesmium are capable of synthesising nitrogenase (Ohki and Taniuchi, 2009). The organisation of the nif operon observed in Trichodesmium is quite similar with the observed in heterocytous cyanobacteria (Bergman et al., 2013), and contrary to other non-heterocytous cyanobacteria, this genus performs nitrogen fixation during the light period (mid-day), linking both spatial and temporal strategies to improve the efficiency of these processes (Berman-Frank et al., 2001). At mid-day, photosynthesis is down-regulated (Finzi-Hart et al., 2009), and respiration, Mehler reaction, and the pentose phosphate pathway are intensified, decreasing the net $\mathrm{O}_{2}$ evolution and providing reducing power (NADPH) for $\mathrm{N}_{2}$ fixation, respectively (Sandh et al., 2011). Finally, the ability to fix $\mathrm{N}_{2}$ observed in Trichodesmium strains was lost in Arthrospira (Spirulina) (Figure 1c) (Larsson et al., 2011), and although nitrogen fixation has been shown by Lyngbya species (Lundgren et al., 2003), a recent study showed the absence of nitrogenase genes in the genome of Lyngbya majuscula 3L (Jones et al., 2011)

Phylogenetic analyses were performed based on $16 \mathrm{~S}$ rRNA and nifD gene nucleotides sequences retrieved from National Center for Biotechnology Information (NCBI), GenBank database. Sequences were selected taking into ac- 
count cyanobacterial taxa from different morphological types. Additionally, for nif $\mathrm{D}$ gene, sequences from noncyanobacterial strains, which also belong to the Bacteria domain, were selected. The nucleotide of nif $\mathrm{D}$ and $16 \mathrm{~S}$ rRNA sequences retrieved from GenBank were aligned separately using the Muscle algorithm (Edgar, 2004) provided in MEGA 5.0 (Tamura et al., 2011). A total of 39 and 54 sequences were used for nifD and 16S rRNA phylogenetic analyses, respectively. For nif $\mathrm{D}$ gene sequences, a matrix with 6,904 base pair lenght was obtained and a matrix with 1,463 base pair lenght was obtained for 16S rRNA sequences. Optimal evolutionary models were selected using MrModelTest 2.3 (Nylander, 2004) under the Akaike information criterion (AIC). Phylogenetic trees were reconstructed using the maximum-likelihood (ML) and Bayesian methods. For Bayesian analysis, the trees were searched using the software MrBayes 3.2.6 (Ronquist et al., 2012). Posterior probabilities (PP) were calculated at the conclusion of the Markov-Chain-Monte-Carlo analysis and a traditional burn-in on the first $25 \%$ of the trees was performed. The Bayesian topology was visualized using the FigTree v1.3.1.program (Rambaut, 2009). The ML trees were reconstructed using the MEGA program package, version 5 (Tamura et al., 2011). The robustness of the phylogenetic trees was estimated via bootstrap analysis using 1000 replications.

Results obtained using nifD gene sequences support the monophyly of cyanobacteria, with a group of Proteobacteria as a sister group and a Klebsiella sequence as root (Figure 3). Indeed, previous analyses of the catalytic subunits of this enzyme complex indicate that the enzyme existed prior to the oxygenation of Earth's atmosphere (Latysheva et al., 2012). Our phylogenetic analyses also demonstrated that the cyanobacterial nifD sequences group in a very similar way to the $16 \mathrm{~S}$ rRNA topology, supporting a vertical ancestry of $\mathrm{N}_{2}$ fixation among cyanobacteria (Figures 3 and 4). The heterocytous cyanobacteria form a monophyletic lineage, with true branching cyanobacteria placed within the non-branching cyanobacteria group (Figure 3), indicating that the nif $\mathrm{D}$ gene from heterocytous strains share a common ancestor (Figure 3). Based on nifD gene sequences, cyanobacterial morphotypes belonging to Chroococcales and Synechococcales (unicellular), and Oscillatoriales/Pseudanabaenales (filamentous non-heterocytous) constitute polyphyletic groups (Figure 3). Taken together, these data indicate that morphological features and 16S rRNA phylogeny data are highly correlated with the evolutionary history of the nifD gene (Figures 1, 3 and 4), at least for this dataset, and mainly based on order level. It is important to mention however, that the monophyletic origin of nif $\mathrm{D}$ cannot be directly associated with morphological aspects. The phylogenetic reconstruction based on 16S rRNA sequences suggest that all heterocytous cyanobacteria (Nostocales) form a single monophyletic group (Henson et al., 2004a; Tomitani et al., 2006; Shih et al.,
2013) and support the polyphyly of true branching cyanobacteria (Figure 4). In addition, our analysis corroborates other molecular data from 16S rRNA sequences that demonstrate a polyphyletic origin of the unicellular and filamentous homocytous strains (Figure 4) (Litvaitis, 2002; Valério et al., 2009; Andreote et al., 2014; Silva et al., 2014).

\section{The importance of an evolutionary pressure for $\mathrm{N}_{2}$ fixation}

Careful phylogenetic analyses using 57 nif $\mathrm{D}$ nucleotide sequences and inferred amino acids sequences (Henson et al., 2004b), and also proteins sets from 49 cyanobacterial genomes (Latysheva et al., 2012), suggest the presence of a nitrogen fixing cyanobacteria common ancestor. This implies that $\mathrm{N}_{2}$-fixation genes had arisen approximately 3 billion years ago (Latysheva et al., 2012) and lends support for the results observed in Figure 3. It has been assumed that fixed nitrogen was a limiting resource in the early Earth environment (Raven and Yin, 1998; Kasting and Siefert, 2001 ), once a decrease in the atmospheric $\mathrm{CO}_{2}$ concentration in the early Archaean ( $\sim 3.5$ billion years ago) might have entailed in a small availability of reduced nitrogen forms, synthesized from $\mathrm{N}_{2}$ and $\mathrm{CO}_{2}$ (Navarro-Gonzalez et al., 2001). In addition, in this period, the Earth's reduced atmosphere might have allowed fixed nitrogen compounds to be stable (Kasting and Siefert, 2001, 2002). Altogether, these conditions, probably, were able to favour an evolutionary pressure for the establishment of a biological $\mathrm{N}_{2}$ fixation process at an early stage of prokaryotic evolution (Towe, 2002). Assuming that the origin of nitrogenase pre-dates the origin of $\mathrm{N}_{2}$ fixation, it is likely that respiratory enzymes or cyanide detoxification centers had been involved in this process (Fani et al., 2000). Our data indicate that all cyanobacteria strains able to fix $\mathrm{N}_{2}$ are forming a monophyletic group when compared with the other, paraphyletic eubacteria group, suggesting that the intrinsic ability to fix $\mathrm{N}_{2}$ in cyanobacteria was most likely obtained directly from a common ancestor (Figure 3). Information from phylogenetic reconstructions and also the presence of nif genes in many groups of archaea and bacteria suggest that nitrogenase had already evolved within the last common ancestor (LCA) (Normand et al., 1992; Fani et al., 2000). However, it remains unclear whether the present distribution of $n$ if genes in cyanobacteria has been obtained by horizontal gene transfer (HGT), or whether vertical descent had a larger impact on this process (Henson et al., 2004b; Latysheva et al., 2012). In the LCA hypothesis, the loss of nitrogenase genes by some groups reflects the modern scattered distribution of these among both Archaea and Bacteria, but not in all phyla, and neither in eukaryotes (Raymond et al., 2004; Latysheva et al., 2012). Meanwhile, HGT and genetic duplication events could happened between and within prokaryotic lines, helping to explain the 


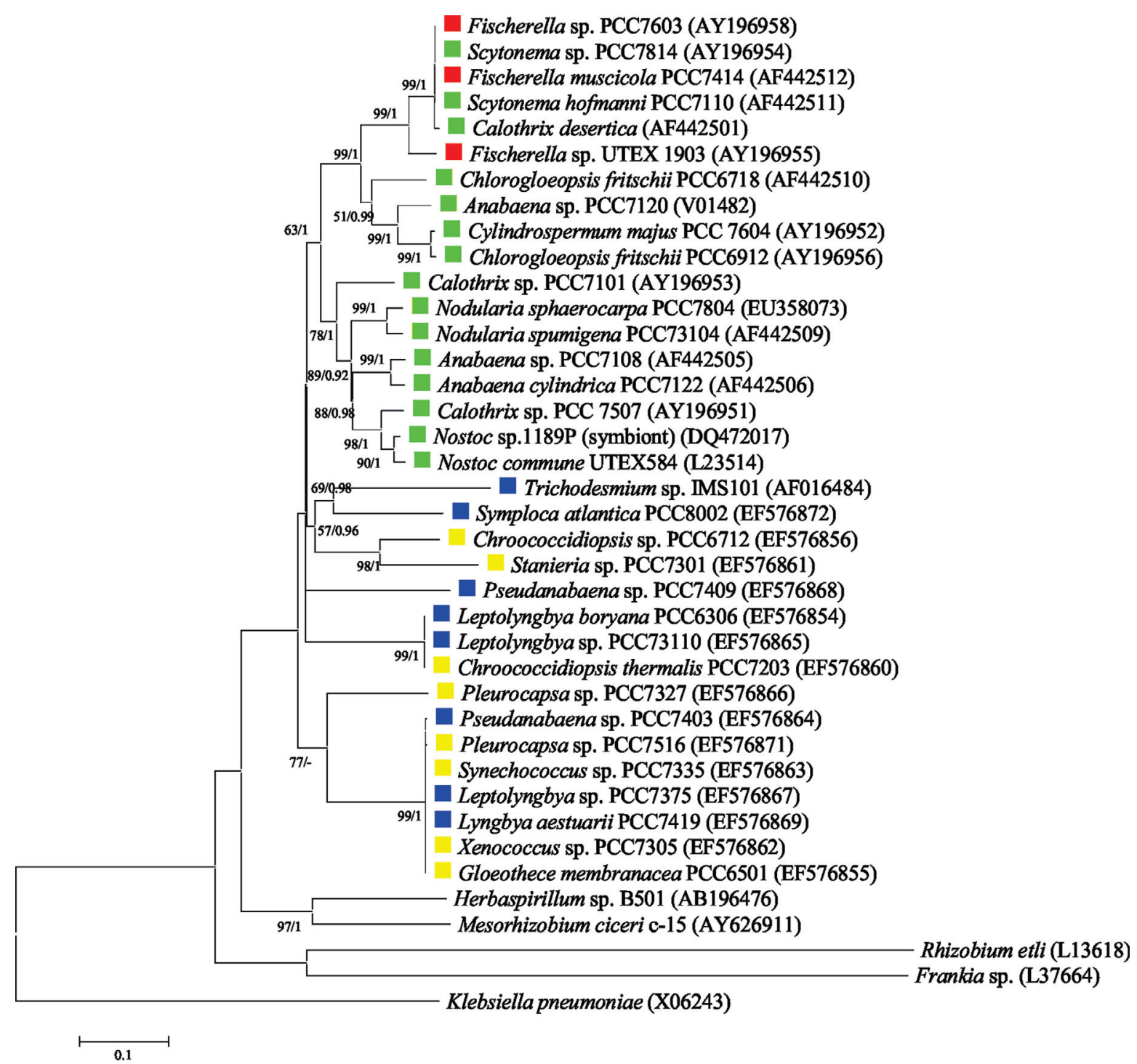

Figure 3 - Maximum Likelihood (ML) phylogenetic reconstruction based on partial nifD gene sequences. A total of 39 nucleotide sequences of $\alpha$-subunit of dinitrogenase were used. A matrix with 6,904 base pair lenght was obtained after alingment. The general time reversible evolutionary model of substitution with gamma distribution and with an estimate of proportion of invariable sites (GTR $+\mathrm{G}+\mathrm{I})$ was selected as the fittest for the alignment by MrModelTest 2.3 (Nylander, 2004). Phylogenetic trees were reconstructed using the ML and Bayesian methods. For Bayesian analysis, the trees were searched using the software MrBayes 3.2.6 (Ronquist et al., 2012) and the Bayesian analysis consisted of two independent runs, with four Markov chains each, of 50 million generations sampled every 5,000 generations. Posterior probabilities (PP) were calculated at the conclusion of the MarkovChain-Monte-Carlo analysis and a traditional burn-in on the first $25 \%$ of the trees was performed. The ML trees were reconstructed using the MEGA program package, version 5 (Tamura et al., 2011). The robustness of the phylogenetic trees was estimated via bootstrap analysis using 1,000 replications. ML and Bayesian methods resulted in nearly identical topologies, with indications of bootstrap values (ML) and Bayesian PPs in the relevant nodes. The cyanobacterial morphologies are highlighted with different colours: yellow for unicellular strains, blue for filamentous non-heterocytous strains, green for filamentous heterocytous strains without branching, and red for filamentous heterocytous strains with true branching. Sequence data from this article can be found in the NCBI database under the accession numbers, which are presented together with the strain name.

presence of more than one nitrogenase gene copy in some bacteria (Kechris et al., 2006). These copies could be related to a new nitrogenase family, which presents a different metal co-factor (Fe or V nitrogenases) (Thiel, 1993; Pratte et al., 2006), showing that HGT is most likely a source of genetic diversity in cyanobacteria (Mulkidjanian et al., 2006).

Given the crucial importance of nitrogenase for cyanobacterial $\mathrm{N}_{2}$ fixation, it is not surprising that alterna- tive nitrogenases have been found (Eady, 1996; Masukawa et al., 2009). Cyanobacteria have co-evolved during the course of planetary evolution and was already present when the change of oxidation state of both ocean and atmosphere occurred (Berman-Frank et al., 2003). The low oxygen concentration in the early Earth might have acted as a selective pressure on nitrogenase, once information from paleosols indicates a high availability of reduced Fe rather than Mo. Then, a nitrogenase able to use Fe as a metal- 


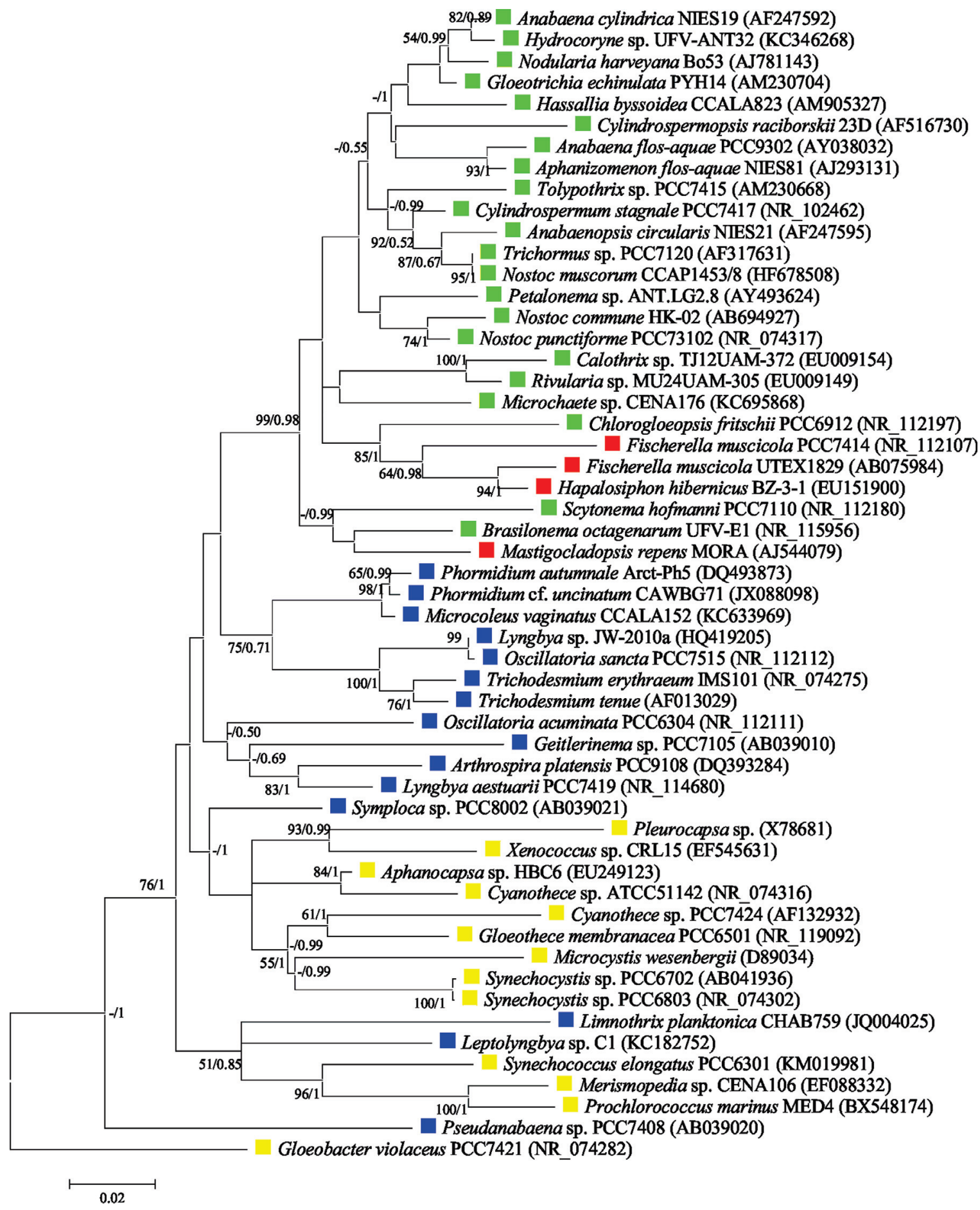

Figure 4 - Maximum Likelihood (ML) phylogenetic reconstruction based on partial 16S rRNA sequences. A total of 54 sequences were used. A matrix with 1,463 base pair lenght was obtained after alingment. The general time reversible evolutionary model of substitution with gamma distribution and with an estimate of proportion of invariable sites (GTR + G + I) was selected as the fittest for the alignment by MrModelTest 2.3 (Nylander, 2004). Phylogenetic trees were reconstructed using the ML and Bayesian methods. For Bayesian analysis, the trees were searched using the software MrBayes 3.2.6 (Ronquist et al., 2012) and the Bayesian analysis consisted of two independent runs, with four Markov chains each, of 50 million generations sampled every 5,000 generations. Posterior probabilities (PP) were calculated at the conclusion of the Markov-Chain-Monte-Carlo analysis and a traditional burn-in on the first $25 \%$ of the trees was performed. The ML trees were reconstructed using the MEGA program package, version 5 (Tamura et al., 2011). The robustness of the phylogenetic trees was estimated via bootstrap analysis using 1000 replications. ML and Bayesian methods resulted in nearly identical topologies, with indications of bootstrap values (ML) and Bayesian PPs in the relevant nodes. The cyanobacterial morphologies are highlighted with different colours: yellow for unicellular strains, blue for filamentous non-heterocytous strains, green for filamentous heterocytous strains without branching, and red for filamentous heterocytous strains with true branching. Sequence data from this article can be found in the NCBI database under the accession numbers, which are presented together with the strain name. 
cofactor would have been in great advantage (Anbar and Knoll, 2002). Accordingly, some physiological evidence has been presented for the existence of a Fe-nitrogenase in Anabaena variabilis (Kentemich et al., 1991). In addition, a V-nitrogenase has been found only in the genera Anabaena (A. variabilis and A. azotica) and Nostoc (Kentemich et al., 1988; Thiel, 1993; Masukawa et al., 2009). The divergence between the Fe-dependent and V-dependent nitrogenases most likely occurred subsequently in the evolutionary history, and it is therefore reasonable to suggest that an ancestral NifD homolog might have had lower specificity with respect to its metal cofactor (Raymond et al., 2004). The cyanobacterial photosynthesis led to a progressive increase of the atmospheric oxygen concentration in the Precambrian Earth, affecting negatively Fe availability. On the other hand, soluble oxidized Mo started to become more available in the oceans (Hofmann, 1976; Bekker et al., 2004; Frei et al., 2009). Thus, nitrogenase would be responsive for the environmental availability of $\mathrm{V}, \mathrm{Fe}$, and Mo that fluctuated with the changing redox state that characterised the Proterozoic Earth between 1 and 2 billion years ago (Normand and Bousquet, 1989; Anbar and Knoll, 2002). Furthermore, in addition to the higher availability of Mo, an increased efficiency of Mo-nitrogenase, compared with both V- and Fe-dependent enzymes, could also act as an additional selection pressure factor for the establishment of the Mo-dependent nitrogenase (Raymond et al., 2004). Growth rates registered on $\mathrm{V}$ and Mo cultures of $A$. variabilis were essentially the same, although the catalytic efficiency of the alternative nitrogenase was lower than the one presented by the MoFe-nitrogenase (Kentemich et al., 1988). In addition, the specific activity of the VFe-nitrogenase, at $30^{\circ} \mathrm{C}$, in Azotobacter is approximately 1.5 times lower than that of MoFe-nitrogenase (Miller and Eady, 1988).

\section{Hydrogen biosynthesis and strategies to improve hydrogen production in cyanobacteria}

Molecular hydrogen was an essential source of energy during the early stages of the Earth, but lost its importance with the evolution of the photosynthetic machinery, that was able to use light more efficiently (Esper et al., 2006). In cyanobacteria and other $\mathrm{N}_{2}$-fixing prokaryotes, $\mathrm{H}_{2}$ is synthesized as a by-product of nitrogenase during the $\mathrm{N}_{2}$ fixation process, and in a next step reaction, it may be oxidized by a hydrogenase (Berman-Frank et al., 2003). Accordingly, in addition to nitrogenase, cyanobacteria may possess different enzymes related with $\mathrm{H}_{2}$ metabolism: an uptake hydrogenase which catalyses $\mathrm{H}_{2}$ consumption, and a bidirectional hydrogenase able to catalyse both $\mathrm{H}_{2}$ synthesis and oxidation (Tamagnini et al., 2002). The presence of a bidirectional hydrogenase in cyanobacteria is unrelated with its capacity to fix $\mathrm{N}_{2}$ (Serebriakova et al., 1994; Carrieri et al., 2011). On the other hand, an uptake hydro- genase has been found in almost all the $\mathrm{N}_{2}$-fixing cyanobacteria examined thus far, with one reported exception Synechococcus sp. BG 043511 (Ludwig et al., 2006). The recycling of $\mathrm{H}_{2}$, by hydrogenases, is an important metabolic process, once it generates ATP and reduction equivalents, and provides an anoxic environment to nitrogenase activity (Bothe et al., 2010). As important enzymes in the energy metabolism of microorganisms, hydrogenases are widespread in prokaryotes. The distribution and function of these enzymes has been expertly investigated elsewhere (Ludwig et al., 2006; Barz et al., 2010; Skizim et al., 2012), once $\mathrm{H}_{2}$ is commonly considered as the future of "clean" energy (Dismukes et al., 2008; Quintana et al., 2011). Its combustion, different of fossil fuels, releases water as a product together with high amounts of energy which can be transformed in electricity (Dutta et al., 2005). Furthermore, $\mathrm{H}_{2}$ is an unlimited energy source, and even with the lower efficiency of photobiological systems compared with electrochemical $\mathrm{H}_{2}$ production, this alternative shows economic viability due to the low production cost (Block and Melody, 1992; Lindblad, 1999; Dutta et al., 2005). Notably, $\mathrm{H}_{2}$ production was registered for at least 14 cyanobacterial genera under a vast range of culture growth conditions (Tamagnini et al., 2002), and although both the nitrogenase(s) and the bidirectional hydrogenase are capable of $\mathrm{H}_{2}$ production (Tamagnini et al., 2000), it is reasonable to assume nitrogenase as a key enzyme for cyanobacterial $\mathrm{H}_{2}$ production (Kumazawa and Mitsui, 1994; Yoshino et al., 2007; Sakurai et al., 2015). As discussed above, alternative nitrogenases exhibit lower catalytic activities compared with MoFe-nitrogenase (Kentemich et al., 1988; Miller and Eady, 1988), and might not be assumed as candidates for $\mathrm{H}_{2}$ production (Hallenbeck and Benemann, 2002).

Cyanobacterial photohydrogen production has been already carried out with $\mathrm{N}_{2}$-fixing strains (Lichtl et al., 1997; Tsygankov et al., 1997, 1998) in which the net $\mathrm{H}_{2}$ production is the result between the $\mathrm{H}_{2}$ evolution catalyzed by nitrogenase and $\mathrm{H}_{2}$ consumption catalyzed by the uptake hydrogenase. The inactivation of [NiFe]-uptake hydrogenase in $\mathrm{N}_{2}$-fixing cyanobacteria leads to an efficient increase in the $\mathrm{H}_{2}$ produced: 3 to $7 \mathrm{x}$-fold more than in wild-type cells under optimal conditions (Masukawa et al., 2002; Yoshino et al., 2007). On the other hand, due to the sensitivity of nitrogenase and hydrogenases to $\mathrm{O}_{2}$ (Zehr et al., 1993; Serebryakova et al., 1996; Tamagnini et al., 2002), strategies such as biophotovoltaic cells (BPVs) and anaerobic growth conditions have been tested to separate the $\mathrm{O}_{2}$ for $\mathrm{H}_{2}$ production, in an attempt to improve the yield of this process (Bombelli et al., 2011; Bradley et al., 2013). However, it seems reasonable to assume that another possible solution to this issue is the use of heterocytous cyanobacteria. These organisms appear as an interesting solution given that they present at least two different cell types (veg- 
etative cells and heterocytes), where the $\mathrm{O}_{2}$ and $\mathrm{H}_{2}$ evolving activities occur spatially separated.

Many cyanobacteria are facultative anaerobes that can produce $\mathrm{H}_{2}$ as a by-product of the dark anoxic catabolism of photosynthetic compounds, mainly glycogen (Stal and Moezelaar, 1997; Das and Veziroglu, 2001; McNeely et al., 2010). It was shown that after hydrogenase activation by anaerobic conditions in the dark, the amount of $\mathrm{H}_{2}$ produced at light conditions by an engineered strain of Synechocystis lacking the quinol and cytochrome $c$ oxidase (Gutthann et al., 2007) increased 12 fold compared to wild-type cells (Gutthann et al., 2007). Furthermore, the disruption of the nitrate assimilation pathway produced from 10 to 140 fold more $\mathrm{H}_{2}$ (Baebprasert et al., 2011), and cells supplemented with ammonium, as the nitrogen source, evolved about twofold more $\mathrm{H}_{2}$ than cells grown with nitrate (Baebprasert et al., 2011). Notably, increasing concentrations of nickel (Ni) during cell growth seem to be clearly important for $\mathrm{H}_{2}$ production. Thus, $\mathrm{NiCl}_{2}$ supplementation in Arthrospira maxima kept under low light increases $\mathrm{H}_{2}$ production following anaerobic induction in darkness. Additionally, Ni supplemented cultures evolve $\mathrm{H}_{2}$ at initial rates 18 fold higher than unsupplemented ones (Carrieri et al., 2008). Collectively these results indicate that both metabolic engineering and growth conditions will have clear impacts on $\mathrm{H}_{2}$ production and therefore, further combined studies are required to increase our knowledge on this important cyanobacterial topic.

Although the $\mathrm{H}_{2}$ production in $\mathrm{N}_{2}$-fixing cyanobacteria has been extensively investigated (Kumazawa and Mitsui, 1994; Serebriakova et al., 1994; Kumazawa and Asakawa, 1995; Tsygankov et al., 1997, 1998; Borodin et al., 2000; Masukawa et al., 2002; Yoshino et al., 2007), a focus on non-fixing cyanobacteria strains, mainly Synecochystis sp. PCC6803, has also recently appeared (Gutthann et al., 2007; Baebprasert et al., 2011; McCormick et al., 2013). The availability of its genomic sequence coupled with the acquired ability to be naturally transformable has clearly promoted the usage of this strain. However, recent evidence suggests that Synechococcus sp.WH5701, a $\mathrm{N}_{2}$-fixing cyanobacteria, may have a higher capacity for extracellular electron transport in comparison to Synechocystis (McCormick et al., 2011). Thus, it seems likely that analysing the yield of $\mathrm{N}_{2}$-fixing cyanobacteria in BPVs and in other conditions mentioned here and compare it with Synechocystis, mainly those heterocytous strains with inactivated $[\mathrm{NiFe}]$-uptake hydrogenase (Masukawa et al., 2002; Yoshino et al., 2007), might provide an interesting research avenue to be persued. In addition, it should be kept in mind that, although extensive efforts have been made to produce $\mathrm{H}_{2}$ from cyanobacteria, this approach appears to be still in a very early stage of development (Akkerman et al., 2002; Wijffels et al., 2013), and there- fore, a number of technological aspects, such as the cost of nutrients and bioreactors, should be considered during the design of future plans for photobiological $\mathrm{H}_{2}$ production (Sakurai et al., 2013, 2015). Although, significant challenges remain in the potential developing of cyanobacteria for biological $\mathrm{H}_{2}$ production, we hope that through the use of the above discussed targets, subsequent studies will increase our knowledge and bring us closer to realizing the biotechnological potential of nitrogenase-mediated $\mathrm{H}_{2}$ production by these microorganisms.

\section{Concluding remarks}

Despite the relationships observed here between the nifD sequences with regard to both morphological and molecular (16S rRNA) relationships previously observed in the cyanobacterial group, many open questions remain about cyanobacterial evolution and metabolism. It is reasonable to assume that the different strategies observed in cyanobacteria (spatial and temporal separation) to improve $\mathrm{N}_{2}$ fixation were associated with small alterations in the nif nucleotide sequences, despite large changes in morphology. Our future ability to answer these questions is dependent on fundamental work providing a fuller understanding of these processes and on how they are regulated. Although many biological and technological challenges need to be overcome, we believe that improvement of the $\mathrm{N}_{2}$ fixation process will be directly associated with $\mathrm{H}_{2}$ production as one of the leading contenders for renewable energy. It should also be kept in mind that the development of large-scale and economical photobiological $\mathrm{H}_{2}$ production, which might be linked to improved cyanobacterial $\mathrm{N}_{2}$ fixation, most likely will make meaningful contributions to mitigate climate change and also provide new employment opportunities, particularly in areas unsuitable for modern agriculture.

\section{Acknowledgments}

This work was supported by funding from the Max Planck Society (to A.N.N. and W.L.A.) and the National Council for Scientific and Technological Development (CNPq-Brazil, Grant 483525/2012-0 to W.L.A., Grant 306355/2012-4 to A.N.N.) and the FAPEMIG (Foundation for Research Assistance of the Minas Gerais State, Brazil, Grant APQ- 01106-13 and APQ-01357-14 to W.L.A.). Scholarships granted by CNPq and FAPEMIG to J.H.F.C., by CNPq to A.A.E-F., by Brazilian Federal Agency for Support and Evaluation of Graduate Education (CAPES) to L.V.A. and CAPES/FAPEMIG to M.G.M.V.V. (BPD-00514-14) are also gratefully acknowledged. We also would like to thank the CCALA Culture Collection of Autotrophic Organisms (http://ccala.butbn.cas.cz) and Prof. Ondøej Práil (Institute of Microbiology, Czech Academy of Sciences, Czech Republic) for kindly providing the pictures $\mathrm{c}$ and $\mathrm{d}$ for Figure 1 . 


\section{References}

Akkerman I, Janssen M, Rocha J and Wijffels RH (2002) Photobiological hydrogen production: Photochemical efficiency and bioreactor design. Int J Hydrogen Energ 27:1195-1208.

Alfonso M, Perewoska I and Kirilovsky D (2001) Redox control of $n t c$ A gene expression in Synechocystis sp. PCC 6803. Nitrogen availability and electron transport regulate the levels of the NtcA protein. Plant Physiol 125:969-981.

Anbar AD and Knoll AH (2002) Proterozoic Ocean Chemistry and Evolution: A Bioinorganic Bridge? Science 297:1137-1142.

Andreote APD, Vaz MGMV, Genuário DB, Barbiero L, Rezende-Filho AT and Fiore MF (2014) Nonheterocytous cyanobacteria from Brazilian saline-alkaline lakes. J Phycol 50:675-684.

Baebprasert W, Jantaro S, Khetkorn W, Lindblad P and Incharoensakdi A (2011) Increased $\mathrm{H}_{2}$ production in the cyanobacterium Synechocystis sp. strain PCC 6803 by redirecting the electron supply via genetic engineering of the nitrate assimilation pathway. Metab Eng 13:610-616.

Barz M, Beimgraben C, Staller T, Germer F, Opitz F, Marquardt C, Schwarz C, Gutekunst K, Vanselow KH, Schmitz R, et al. (2010) Distribution analysis of hydrogenases in surface waters of marine and freshwater environments. PLoS ONE 5:e13846.

Beck C, Knoop H, Axmann IM and Steuer R (2012) The diversity of cyanobacterial metabolism: Genome analysis of multiple phototrophic microorganisms. BMC Genomics 13:56.

Bekker A, Holland H, Wang P-L, Rumble D, Stein H, Hannah J, Coetzee L and Beukes N (2004) Dating the rise of atmospheric oxygen. Nature 427:117-120.

Bergman B, Gallon JR, Rai AN and Stal LJ (1997) N 2 Fixation by non-heterocystous cyanobacteria. FEMS Microbiol Rev 19:139-185.

Bergman B, Sandh G, Lin S, Larsson J and Carpenter EJ (2013) Trichodesmium - a widespread marine cyanobacterium with unusual nitrogen fixation properties. FEMS Microbiol Rev 37:286-302.

Berman-Frank I, Lundgren P, Chen Y-B, Küpper H, Kolber Z, Bergman B and Falkowski P (2001) Segregation of nitrogen fixation and oxygenic photosynthesis in the marine cyanobacterium Trichodesmium. Science 294:1534-1537.

Berman-Frank I, Lundgren P and Falkowski P (2003) Nitrogen fixation and photosynthetic oxygen evolution in cyanobacteria. Res Microbiol 154:157-164.

Berman-Frank I, Quigg A, Finkel ZV, Irwin AJ and Haramaty L (2007) Nitrogen-fixation strategies and Fe requirements in cyanobacteria. Limnol Oceanogr 52:2260-2269.

Betancourt DA, Loveless TM, Brown JW and Bishop PE (2008) Characterization of diazotrophs containing Mo-independent nitrogenases, isolated from diverse natural environments. Appl Environ Microb 74:3471-3480.

Block DL and Melody I (1992) Efficiency and cost goals for photoenhanced hydrogen production processes. Int J Hydrogen Energ 17:853-861.

Böhme H (1998) Regulation of nitrogen fixation in heterocystforming cyanobacteria. Trends Plant Sci 3:346-351.

Bombelli P, Bradley RW, Scott AM, Philips AJ, McCormick AJ, Cruz SM, Anderson A, Yunus K, Bendall DS, Cameron PJ, et al. (2011) Quantitative analysis of the factors limiting solar power transduction by Synechocystis sp. PCC 6803 in bi- ological photovoltaic devices. Energy Environ Sci 4:4690-4698.

Borodin VB, Tsygankov AA, Rao KK and Hall DO (2000) Hydrogen production by Anabaena variabilis PK84 under simulated outdoor conditions. Biotechnol Bioeng 69:478-485.

Bothe H, Schmitz O, Yates MG and Newton WE (2010) Nitrogen fixation and hydrogen metabolism in Cyanobacteria. Microbiol Mol Biol R 74:529-551.

Boyd E and Peters JW (2013) New insights into the evolutionary history of biological nitrogen fixation. Front. Microbiol 4:201.

Bradley RW, Bombelli P, Lea-Smith DJ and Howe CJ (2013) Terminal oxidase mutants of the cyanobacterium Synechocystis sp. PCC 6803 show increased electrogenic activity in biological photo-voltaic systems. Phys Chem Chem Phys 15:13611-13618.

Brusca JS, Chastain CJ and Golden JW (1990) Expression of the Anabaena sp. strain PCC 7120 xisA gene from a heterologous promoter results in excision of the nifD element. $\mathrm{J}$ Bacteriol 172:3925-3931.

Burnat M, Herrero A and Flores E (2014) Compartmentalized cyanophycin metabolism in the diazotrophic filaments of a heterocyst-forming cyanobacterium. Proc Natl Acad Sci U S A 111:3823-3828.

Cardona T, Battchikova N, Zhang P, Stensjö K, Aro E-M, Lindblad P and Magnuson A (2009) Electron transfer protein complexes in the thylakoid membranes of heterocysts from the cyanobacterium Nostoc punctiforme. Biochim Biophys Acta - Bioenerget 1787:252-263.

Carrieri D, Ananyev G, Garcia Costas AM, Bryant DA and Dismukes GC (2008) Renewable hydrogen production by cyanobacteria: Nickel requirements for optimal hydrogenase activity. Int J Hydrogen Energ 33:2014-2022.

Carrieri D, Wawrousek K, Eckert C, Yu J and Maness P-C (2011) The role of the bidirectional hydrogenase in cyanobacteria. Bioresource Technol 102:8368-8377.

Colón-López MS, Sherman DM and Sherman LA (1997) Transcriptional and translational regulation of nitrogenase in light-dark- and continuous-light-grown cultures of the unicellular cyanobacterium Cyanothece sp. strain ATCC 51142. J Bacteriol 179:4319-4327.

Curatti L, Flores E and Salerno G (2002) Sucrose is involved in the diazotrophic metabolism of the heterocyst-forming cyanobacterium Anabaena sp. FEBS Lett 513:175-178.

Curatti L, Hernandez JA, Igarashi RY, Soboh B, Zhao D and Rubio LM (2007) In vitro synthesis of the iron-molybdenum cofactor of nitrogenase from iron, sulfur, molybdenum, and homocitrate using purified proteins. Proc Natl Acad Sci U S A 104:17626-17631.

Das D and Veziroglu TN (2001) Hydrogen production by biological processes: A survey of literature. Int J Hydrogen Energ 26:13-28.

Dismukes GC, Carrieri D, Bennette N, Ananyev GM and Posewitz MC (2008) Aquatic phototrophs: Efficient alternatives to land-based crops for biofuels. Curr Opin Biotech 19:235-240.

Dutta D, De D, Chaudhuri S and Bhattacharya S (2005) Hydrogen production by Cyanobacteria. Microb Cell Fact 4:36.

Eady RR (1996) Structure-Function Relationships of Alternative Nitrogenases. Chem Rev 96:3013-3030. 
Edgar RC (2004) MUSCLE: Multiple sequence alignment with high accuracy and high throughput. Nucleic Acids Res 32:1792-1797.

Esper B, Badura A and Rögner M (2006) Photosynthesis as a power supply for (bio-) hydrogen production. Trends Plant Sci 11:543-549.

Falkowski PG (1997) Evolution of the nitrogen cycle and its influence on the biological sequestration of $\mathrm{CO}_{2}$ in the ocean. Nature 387:272-275.

Fani R, Gallo R and Liò P (2000) Molecular evolution of nitrogen fixation: The evolutionary history of the nif $\mathrm{D}$, nifK, nif $\mathrm{E}$, and nif $\mathrm{N}$ genes. J Mol Evol 51:1-11.

Fay P (1992) Oxygen relations of nitrogen fixation in cyanobacteria. Microbiol Rev 56:340-373.

Finzi-Hart JA, Pett-Ridge J, Weber PK, Popa R, Fallon SJ, Gunderson T, Hutcheon ID, Nealson KH and Capone DG (2009) Fixation and fate of $\mathrm{C}$ and $\mathrm{N}$ in the cyanobacterium Trichodesmium using nanometer-scale secondary ion mass spectrometry. Proc Natl Acad Sci U S A 106:6345-6350.

Flores E and Herrero A (2005) Nitrogen assimilation and nitrogen control in cyanobacteria. Biochem Soc Trans 33:164-167.

Flores E and Herrero A (2010) Compartmentalized function through cell differentiation in filamentous cyanobacteria. Nat Rev Micro 8:39-50.

Flores E, Frías JE, Rubio LM and Herrero A (2005) Photosynthetic nitrate assimilation in cyanobacteria. Photosynth Res 83:117-133.

Fredriksson C and Bergman B (1995) Nitrogenase quantity varies diurnally in a subset of cells within colonies of the nonheterocystous cyanobacteria Trichodesmium spp. Microbiology 141:2471-2478.

Fredriksson C and Bergman B (1997) Ultrastructural characterisation of cells specialised for nitrogen fixation in a nonheterocystous cyanobacterium, Trichodesmium spp. Protoplasma 197:76-85.

Frei R, Gaucher C, Poulton SW and Canfield DE (2009) Fluctuations in Precambrian atmospheric oxygenation recorded by chromium isotopes. Nature 461:250-253.

García-Domínguez M and Florencio FJ (1997) Nitrogen availability and electron transport control the expression of $g \ln \mathrm{B}$ gene (encoding PII protein) in the cyanobacterium Synechocystis sp. PCC 6803. Plant Mol Biol 35:723-734.

Golden J and Wiest D (1988) Genome rearrangement and nitrogen fixation in Anabaena blocked by inactivation of xisA gene. Science 242:1421-1423.

Gutthann F, Egert M, Marques A and Appel J (2007) Inhibition of respiration and nitrate assimilation enhances photohydrogen evolution under low oxygen concentrations in Synechocystis sp. PCC 6803. Biochim Biophys Acta - Bioenergetics 1767:161-169.

Hackenberg C, Kern R, Hüge J, Stal LJ, Tsuji Y, Kopka J, Shiraiwa Y, Bauwe H and Hagemann M (2011) Cyanobacterial lactate oxidases serve as essential partners in $\mathrm{N}_{2}$ fixation and evolved into photorespiratory glycolate oxidases in plants. Plant Cell Online 23:2978-2990.

Hallenbeck PC and Benemann JR (2002) Biological hydrogen production; fundamentals and limiting processes. Int J Hydrogen Energ 27:1185-1193.

Heidorn T, Camsund D, Huang H-H, Lindberg P, Oliveira P, Stensjo K and Lindblad P (2011) Synthetic biology in cyanobacteria: Engineering and analyzing novel functions. Methods Enzymol 497:539-579.

Henson BJ, Hesselbrock SM, Watson LE and Barnum SR (2004a) Molecular phylogeny of the heterocystous cyanobacteria (subsections IV and V) based on nifD. Int J Syst Evol Micr 54:493-497.

Henson BJ, Watson LE and Barnum SR (2004b) The evolutionary history of nitrogen fixation, as assessed by NifD. J Mol Evol 58:390-399.

Hernandez JA, Igarashi RY, Soboh B, Curatti L, Dean DR, Ludden PW and Rubio LM (2007) NifX and NifEN exchange NifB cofactor and the VK-cluster, a newly isolated intermediate of the iron-molybdenum cofactor biosynthetic pathway. Mol Microbiol 63:177-192.

Herrero A, Muro-Pastor AM and Flores E (2001) Nitrogen control in Cyanobacteria. J Bacteriol 183:411-425.

Hess WR (2011) Cyanobacterial genomics for ecology and biotechnology. Curr Opin Microbiol 14:608-614.

Hofmann H (1976) Precambrian microflora, Belcher Islands, Canada: Significance and systematics. J Paleontol:1040-1073.

Hu Q, Sommerfeld M, Jarvis E, Ghirardi M, Posewitz M, Seibert M and Darzins A (2008) Microalgal triacylglycerols as feedstocks for biofuel production: Perspectives and advances. Plant J 54:621-639.

$\mathrm{Hu}$ Y, Fay AW, Lee CC and Ribbe MW (2007) P-cluster maturation on nitrogenase MoFe protein. Proc Natl Acad Sci U S A 104:10424-10429.

Jones AC, Monroe EA, Podell S, Hess WR, Klages S, Esquenazi E, Niessen S, Hoover H, Rothmann M, Lasken RS, et al. (2011) Genomic insights into the physiology and ecology of the marine filamentous cyanobacterium Lyngbya majuscula. Proc Nat; Acad Sci U S A 108:8815-8820.

Jones CS and Mayfield SP (2012) Algae biofuels: Versatility for the future of bioenergy. Curr Opin Biotech 23:346-351.

Kasting JF and Siefert JL (2001) Biogeochemistry: The nitrogen fix. Nature 412:26-27.

Kasting JF and Siefert JL (2002) Life and the evolution of Earth's atmosphere. Science 296:1066-1068.

Kechris KJ, Lin JC, Bickel PJ and Glazer AN (2006) Quantitative exploration of the occurrence of lateral gene transfer by using nitrogen fixation genes as a case study. Proc Natl Acad Sci U S A 103:9584-9589.

Keeling PJ (2013) The number, speed, and impact of plastid endosymbioses in eukaryotic evolution. Annu Rev Plant Biol 64:583-607.

Kentemich T, Danneberg G, Hundeshagen B and Bothe H (1988) Evidence for the occurrence of the alternative, vanadiumcontaining nitrogenase in the cyanobacterium Anabaena variabilis. FEMS Microbiol Lett 51:19-24.

Kentemich T, Haverkamp G and Bothe H (1991) The expression of a third nitrogenase in the cyanobacterium Anabaena variabilis. Z Naturforsch 46c:217-222.

Kim S and Burgess BK (1996) Evidence for the direct interaction of the nif $\mathrm{W}$ gene product with the MoFe protein. J Biol Chem 271:9764-9770.

Knoll AH (2008) Cyanobacteria and earth history. In: Herrero A and Flore E (eds) The Cyanobacteria: Molecular Biology, Genomics and Evolution. 1stedition. Caister Academic Press, Poole, pp 1-19. 
Koonin E (2010) The origin and early evolution of eukaryotes in the light of phylogenomics. Genome Biol 11:209.

Kumazawa S and Asakawa H (1995) Simultaneous production of and $\mathrm{O}_{2}$ in closed vessels by marine Cyanobacterium Anabaena sp. TU37-1 under high-cell-density conditions. Biotechnol Bioeng 46:396-398.

Kumazawa S and Mitsui A (1994) Efficient Hydrogen photoproduction by synchronously grown cells of a marine cyanobacterium, Synechococcus sp. Miami BG 043511, under high cell density conditions. Biotechnol Bioeng 44:854-858.

Larsson J, Nylander JAA and Bergman B (2011) Genome fluctuations in cyanobacteria reflect evolutionary, developmental and adaptive traits. BMC Evol Biol 11:187.

Latysheva N, Junker VL, Palmer WJ, Codd GA and Barker D (2012) The evolution of nitrogen fixation in cyanobacteria. Bioinformatics 28:603-606.

Lee H-M, Vázquez-Bermúdez MF and de Marsac NT (1999) The global nitrogen regulator NtcA regulates transcription of the signal transducer PII $(\mathrm{GlnB})$ and influences its phosphorylation level in response to nitrogen and carbon supplies in the cyanobacterium Synechococcus sp. strain PCC 7942. J Bacteriol 181:2697-2702.

Lichtl RR, Bazin MJ and Hall DO (1997) The biotechnology of hydrogen production by Nostoc flagelliforme grown under chemostat conditions. Appl Microbiol Biot 47:701-707.

Lin S, Henze S, Lundgren P, Bergman B and Carpenter EJ (1998) Whole-cell immunolocalization of nitrogenase in marine diazotrophic cyanobacteria, Trichodesmium spp. Appl Environ Microbiol 64:3052-3058.

Lindblad P (1999) Cyanobacterial $\mathrm{H}_{2}$ metabolism: Knowledge and potential strategies for a photobiotechnological production of $\mathrm{H}_{2}$. Biotecnol Aplic 16:141-144.

Litvaitis MK (2002) A molecular test of cyanobacterial phylogeny: Inferences from constraint analyses. Hydrobiologia 468:135-145.

Ludwig M, Schulz-Friedrich R and Appel J (2006) Occurrence of hydrogenases in cyanobacteria and anoxygenic photosynthetic bacteria: Implications for the phylogenetic origin of cyanobacterial and algal hydrogenases. J Mol Evol 63:758-768.

Lundgren P, Bauer K, Lugomela C, Söderbäck E and Bergman B (2003) Reevaluation of the nitrogen fixation behavior in the marine non-heterocystous cyanobacterium Lyngbya majuscula. J Phycol 39:310-314.

Luque I, Flores E and Herrero A (1994) Molecular mechanism for the operation of nitrogen control in cyanobacteria. EMBO J 13:2862-2869.

Luque I, Zabulon G, Contreras A and Houmard J (2001) Convergence of two global transcriptional regulators on nitrogen induction of the stress-acclimation gene $n b l \mathrm{~A}$ in the cyanobacterium Synechococcus sp. PCC 7942. Mol Microbiol 41:937-947.

Machado IMP and Atsumi S (2012) Cyanobacterial biofuel production. J Biotechnol 162:50-56.

Masukawa H, Mochimaru M and Sakurai H (2002) Disruption of the uptake hydrogenase gene, but not of the bidirectional hydrogenase gene, leads to enhanced photobiological hydrogen production by the nitrogen-fixing cyanobacterium Anabaena sp. PCC 7120. Appl Microbiol Biot 58:618-624.

Masukawa H, Zhang X, Yamazaki E, Iwata S, Nakamura K, Mochimaru M, Inoue K and Sakurai H (2009) Survey of the distribution of different types of nitrogenases and hydrogenases in heterocyst-forming cyanobacteria. Mar Biotechnol 11:397-409.

Mayer SM, Gormal CA, Smith BE and Lawson DM (2002) Crystallographic analysis of the MoFe protein of nitrogenase from a nif $\mathrm{V}$ mutant of Klebsiella pneumoniae identifies citrate as a ligand to the molybdenum of iron molybdenum cofactor (FeMoco). J Biol Chem 277:35263-35266.

McCormick AJ, Bombelli P, Scott AM, Philips AJ, Smith AG, Fisher AC and Howe CJ (2011) Photosynthetic biofilms in pure culture harness solar energy in a mediatorless biophotovoltaic cell (BPV) system. Energy Environ Sci 4:4699-4709.

McCormick AJ, Bombelli P, Lea-Smith DJ, Bradley RW, Scott AM, Fisher AC, Smith AG and Howe CJ (2013) Hydrogen production through oxygenic photosynthesis using the cyanobacterium Synechocystis sp. PCC 6803 in a bio-photoelectrolysis cell (BPE) system. Energy Environ Sci 6:2682-2690.

McNeely K, Xu Y, Bennette N, Bryant DA and Dismukes GC (2010) Redirecting reductant flux into hydrogen production via metabolic engineering of fermentative carbon metabolism in a cyanobacterium. Appl Environ Microbiol 76:5032-5038.

Miller RW and Eady RR (1988) Molybdenum and vanadium nitrogenases of Azotobacter chroococcum. Low temperature favours $\mathrm{N}_{2}$ reduction by vanadium nitrogenase. Biochem. J 256:429-432.

Mulkidjanian A, Koonin E, Makarova K, Mekhedov S, Sorokin A, Wolf Y, Dufresne A, Partensky F, Burd H, Kaznadzey D, et al. (2006) The cyanobacterial genome core and the origin of photosynthesis. Proc Natl Acad Sci U S A 103:13126-13131.

Muro-Pastor MI, Reyes JC and Florencio FJ (1996) The $\mathrm{NADP}^{+}$-isocitrate dehydrogenase gene $(i c d)$ is nitrogen regulated in cyanobacteria. J Bacteriol 178:4070-4076.

Muro-Pastor AM, Valladares A, Flores E and Herrero A (2002) Mutual dependence of the expression of the cell differentiation regulatory protein HetR and the global nitrogen regulator NtcA during heterocyst development. Mol Microbiol 44:1377-1385.

Murry M and Wolk CP (1989) Evidence that the barrier to the penetration of oxygen into heterocysts depends upon two layers of the cell envelope. Arch Microbiol 151:469-474.

Navarro-Gonzalez R, McKay CP and Mvondo DN (2001) A possible nitrogen crisis for Archaean life due to reduced nitrogen fixation by lightning. Nature 412:61-64.

Normand P and Bousquet J (1989) Phylogeny of nitrogenase sequences in Frankia and other nitrogen-fixing microorganisms. J Mol Evol 29:436-447.

Normand P, Gouy M, Cournoyer B and Simonet P (1992) Nucleotide sequence of nifD from Frankia alni strain ArI3: Phylogenetic inferences. Mol Biol Evol 9:495-506.

Nylander J (2004) MrModeltest v2. Program distributed by the author. Evolutionary Biology Centre, Uppsala University.

Ogawa T and Sonoike K (2015) Dissection of respiration and photosynthesis in the cyanobacterium Synechocystis sp. PCC6803 by the analysis of chlorophyll fluorescence. J Photochem Photobiol B 144:61-67.

Ohki K and Taniuchi Y (2009) Detection of nitrogenase in individual cells of a natural population of Trichodesmium using 
immunocytochemical methods for fluorescent cells. J Oceanogr 65:427-432.

Orme-Johnson W (1992) Nitrogenase structure: Where to now? Science 257:1639-1640.

Ow SY, Noirel J, Cardona T, Taton A, Lindblad P, Stensjo K and Wright PC (2008) Quantitative overview of $\mathrm{N}_{2}$ fixation in Nostoc punctiforme ATCC 29133 through cellular enrichments and iTRAQ shotgun proteomics. J Proteome Res 8:187-198.

Paerl H (2012) Marine plankton. In: Whitton BA (ed) Ecology of Cyanobacteria II. Springer, Dordrecht, pp 127-153.

Parmar A, Singh NK, Pandey A, Gnansounou E and Madamwar D (2011) Cyanobacteria and microalgae: A positive prospect for biofuels. Bioresource Technol 102:10163-10172.

Paz-Yepes J, Flores E and Herrero A (2003) Transcriptional effects of the signal transduction protein $\mathrm{P}(\mathrm{II})(g \ln \mathrm{B}$ gene product) on NtcA-dependent genes in Synechococcus sp. PCC 7942. FEBS Lett 543:42-46.

Paz-Yepes J, Herrero A and Flores E (2007) The NtcA-regulated $a m t \mathrm{~B}$ gene is necessary for full methylammonium uptake activity in the cyanobacterium Synechococcus elongatus. J Bacteriol 189:7791-7798.

Pratte BS and Thiel T (2014) Regulation of nitrogenase gene expression by transcript stability in the Cyanobacterium Anabaena variabilis. J Bacteriol 196:3609-3621.

Pratte BS, Eplin K and Thiel T (2006) Cross-functionality of nitrogenase components $\mathrm{NifH} 1$ and $\mathrm{VnfH}$ in Anabaena variabilis. J Bacteriol 188:5806-5811.

Pulz O and Gross W (2004) Valuable products from biotechnology of microalgae. Appl Microbiol Biot 65:635-648.

Quintana N, Van der Kooy F, Van de Rhee MD, Voshol GP and Verpoorte R (2011) Renewable energy from Cyanobacteria: Energy production optimization by metabolic pathway engineering. Appl Microbiol Biot 91:471-490.

Rastogi R, Richa, Sinha R, Singh S and Häder D-P (2010) Photoprotective compounds from marine organisms. J Ind Microbiol Biot 37:537-558.

Raven JA and Yin ZH (1998) The past, present and future of nitrogenous compounds in the atmosphere, and their interactions with plants. New Phytol 139:205-219.

Raymond J, Siefert JL, Staples CR and Blankenship RE (2004) The natural history of nitrogen fixation. Mol Biol Evol 21:541-554.

Renström-Keliner E, Rai AN and Bergman B (1990) Correlation between nitrogenase and glutamine synthetase expression in the cyanobacterium Anabaena cylindrical. Physiol Plantarum 80:12-19.

Reyes J, Muro-Pastor M and Florencio F (1997) Transcription of glutamine synthetase genes $(g \ln \mathrm{A}$ and $g \ln \mathrm{N})$ from the cyanobacterium Synechocystis sp. strain PCC 6803 is differently regulated in response to nitrogen availability. $\mathrm{J}$ Bacteriol 179:2678-2689.

Rodriguez IB and Ho T-Y (2014) Diel nitrogen fixation pattern of Trichodesmium: The interactive control of light and Ni. Sci Rep 4:4445.

Ronquist F, Teslenko M, van der Mark P, Ayres DL, Darling A, Höhna S, Larget B, Liu L, Suchard MA and Huelsenbeck JP (2012) MrBayes 3.2: Efficient Bayesian phylogenetic inference and model choice across a large model space. Syst Biol 61:539-542.
Rubio LM and Ludden PW (2008) Biosynthesis of the ironmolybdenum cofactor of nitrogenase. Annu Rev Microbiol 62:93-111.

Ruffing AM (2011) Engineered cyanobacteria: Teaching an old bug new tricks. Bioeng Bugs 2:136-149.

Sakurai H, Masukawa H, Kitashima M and Inoue K (2013) Photobiological hydrogen production: Bioenergetics and challenges for its practical application. J Photoch Photobio C 17:1-25

Sakurai H, Masukawa H, Kitashima M and Inoue K (2015) How close we are to achieving commercially viable large-scale photobiological hydrogen production by cyanobacteria: A review of the biological aspects. Life 5:997-1018.

Sandh G, Ran L, Xu L, Sundqvist G, Bulone V and Bergman B (2011) Comparative proteomic profiles of the marine cyanobacterium Trichodesmium erythraeum IMS101 under different nitrogen regimes. Proteomics 11:406-419.

Sandh G, Xu L and Bergman B (2012) Diazocyte development in the marine diazotrophic cyanobacterium Trichodesmium. Microbiology 158:345-352.

Savage N (2011) Algae: The scum solution. Nature 474:S15-S16.

Schirrmeister BE, de Vos JM, Antonelli A and Bagheri HC (2013) Evolution of multicellularity coincided with increased diversification of cyanobacteria and the Great Oxidation Event. Proc Natl Acad Sci U S A 110:1791-1796.

Schrautemeier B, Neveling U and Schmitz S (1995) Distinct and differently regulated Mo-dependent nitrogen-fixing systems evolved for heterocysts and vegetative cells of Anabaena variabilis ATCC 29413: Characterization of the $f d x \mathrm{H} 1 / 2$ gene regions as part of the nif $1 / 2$ gene clusters. Mol Microbiol 18:357-369.

Seefeldt LC, Hoffman BM and Dean DR (2009) Mechanism of Mo-dependent nitrogenase. Annu Rev Biochem 78:701-722.

Serebriakova L, Zorin N and Lindblad P (1994) Reversible hydrogenase in Anabaena variabilis ATCC 29413. Arch Microbiol 161:140-144.

Serebryakova LT, Medina M, Zorin NA, Gogotov IN and Cammack R (1996) Reversible hydrogenase of Anabaena variabilis ATCC 29413: Catalytic properties and characterization of redox centres. FEBS Lett 383:79-82.

Shih PM, Wu D, Latifi A, Axen SD, Fewer DP, Talla E, Calteau A, Cai F, Tandeau de Marsac N, Rippka R, et al. (2013) Improving the coverage of the cyanobacterial phylum using diversity-driven genome sequencing. Proc Natl Acad Sci U S A 110:1053-1058.

Silva CSP, Genuário DB, Vaz MGMV and Fiore MF (2014) Phylogeny of culturable cyanobacteria from Brazilian mangroves. Syst Appl Microbiol 37:100-112.

Simpson F and Burris R (1984) A nitrogen pressure of 50 atmospheres does not prevent evolution of hydrogen by nitrogenase. Science 224:1095-1097.

Skizim NJ, Ananyev GM, Krishnan A and Dismukes GC (2012) Metabolic pathways for photobiological hydrogen production by nitrogenase- and hydrogenase-containing unicellular cyanobacteria Cyanothece. J Biol Chem 287:2777-2786.

Staal M, Rabouille S and Stal LJ (2007) On the role of oxygen for nitrogen fixation in the marine cyanobacterium Trichodesmium sp. Environ Microbiol 9:727-736.

Stal L, Severin I and Bolhuis H (2010) The ecology of nitrogen fixation in cyanobacterial mats. In: Hallenbeck PC (ed) Re- 
cent Advances in Phototrophic Prokaryotes, Vol 675. Springer, New York, pp 31-45.

Stal LJ (2008) Nitrogen fixation in cyanobacteria. Encyclopedia of Life Sciences (ELS), pp 1-8.

Stal LJ and Moezelaar R (1997) Fermentation in cyanobacteria. FEMS Microbiol Rev 21:179-211.

Staley JT and Reysenbach A-L (2002) Biodiversity of microbial life: Foundation of earth's biosphere. Wiley \& Sons, Hoboken, pp 592.

Steinhauser D, Fernie AR and Araújo WL (2012) Unusual cyanobacterial TCA cycles: Not broken just different. Trends Plant Sci 17:503-509.

Steunou A-S, Bhaya D, Bateson MM, Melendrez MC, Ward DM, Brecht E, Peters JW, Kühl M and Grossman AR (2006) In situ analysis of nitrogen fixation and metabolic switching in unicellular thermophilic cyanobacteria inhabiting hot spring microbial mats. Proc Natl Acad Sci U S A 103:2398-2403.

Steunou A-S, Jensen SI, Brecht E, Becraft ED, Bateson MM, Kilian O, Bhaya D, Ward DM, Peters JW, Grossman AR, et al. (2008) Regulation of nif gene expression and the energetics of $\mathrm{N}_{2}$ fixation over the diel cycle in a hot spring microbial mat. ISME J 2:364-378.

Suzuki I, Horie N, Sugiyama T and Omata T (1995) Identification and characterization of two nitrogen-regulated genes of the cyanobacterium Synechococcus sp. strain PCC7942 required for maximum efficiency of nitrogen assimilation. $\mathrm{J}$ Bacteriol 177:290-296.

Tamagnini P, Costa JL, Almeida L, Oliveira MJ, Salema R and Lindblad P (2000) Diversity of cyanobacterial hydrogenases, a molecular approach. Curr Microbiol 40:356-361.

Tamagnini P, Axelsson R, Lindberg P, Oxelfelt F, Wünschiers R and Lindblad P (2002) Hydrogenases and hydrogen metabolism of cyanobacteria. Microbiol Mol Biol R 66:1-20.

Tamura K, Peterson D, Peterson N, Stecher G, Nei M and Kumar S (2011) MEGA5: Molecular Evolutionary Genetics Analysis using maximum likelihood, evolutionary distance, and maximum parsimony methods. Mol Biol Evol 28:2731-2739.

Thiel T (1993) Characterization of genes for an alternative nitrogenase in the cyanobacterium Anabaena variabilis. J Bacteriol 175:6276-6286.

Thiel T and Pratte B (2001) Effect on heterocyst differentiation of nitrogen fixation in vegetative cells of the cyanobacterium Anabaena variabilis ATCC 29413. J Bacteriol 183:280-286.

Thiel T and Pratte BS (2014) Regulation of three nitrogenase gene clusters in the cyanobacterium Anabaena variabilis ATCC 29413. Life 4:944-967.

Thiel T, Lyons EM, Erker JC and Ernst A (1995) A second nitrogenase in vegetative cells of a heterocyst-formin and cyanobacterium. Proc Natl Acad Sci U S A 92:9358-9362.

Thiel T, Lyons EM and Erker JC (1997) Characterization of genes for a second Mo-dependent nitrogenase in the cyanobacterium Anabaena variabilis. J Bacteriol 179:5222-5225.

Tomitani A, Knoll AH, Cavanaugh CM and Ohno T (2006) The evolutionary diversification of cyanobacteria: Molecularphylogenetic and paleontological perspectives. Proc Nat Acad Sci U S A 103:5442-5447.

Towe KM (2002) Evolution of nitrogen fixation. Science 295:798-799.

Tsygankov AA, Serebryakova LT, Rao KK and Hall DO (1998) Acetylene reduction and hydrogen photoproduction by wild-type and mutant strains of Anabaena at different $\mathrm{CO}_{2}$ and $\mathrm{O}_{2}$ concentrations. FEMS Microbiol Lett 167:13-17.

Tsygankov AS, Serebryakova LT, Sveshnikov DA, Rao KK, Gogotov IN and Hall DO (1997) Hydrogen photoproduction by three different nitrogenases in whole cells of Anabaena variabilis and the dependence on $\mathrm{pH}$. Int J Hydrogen Energ 22:859-867.

Valério E, Chambel L, Paulino S, Faria N, Pereira P and Tenreiro R (2009) Molecular identification, typing and traceability of cyanobacteria from freshwater reservoirs. Microbiology 155:642-656.

Valladares A, Muro-Pastor AM, Fillat MF, Herrero A and Flores E (1999) Constitutive and nitrogen-regulated promoters of the pet $\mathrm{H}$ gene encoding ferredoxin: NADP+reductase in the heterocyst-forming cyanobacterium Anabaena sp. FEBS Lett 449:159-164.

Valladares A, Montesinos ML, Herrero A and Flores E (2002) An ABC-type, high-affinity urea permease identified in cyanobacteria. Mol Microbiol 43:703-715.

Vázquez-Bermúdez MAF, Herrero A and Flores E (2002) 2-Oxoglutarate increases the binding affinity of the NtcA (nitrogen control) transcription factor for the Synechococcus $g \ln A$ promoter. FEBS Lett 512:71-74.

Walsby AE (1985) The permeability of heterocysts to the gases nitrogen and oxygen. Proc R Soc B 226:345-366.

Walsby AE (2007) Cyanobacterial heterocysts: Terminal pores proposed as sites of gas exchange. Trends Microbiol 15:340-349.

Wijffels RH, Kruse O and Hellingwerf KJ (2013) Potential of industrial biotechnology with cyanobacteria and eukaryotic microalgae. Curr Opin Biotech 24:405-413.

Wilde A and Dienst D (2011) Tools for genetic manipulation of cyanobacteria. In: Peschek GA, Obinger C and Renger G (eds) Bioenergetic Processes of Cyanobacteria. Springer, Dordrecht, pp 685-703.

Yoshino F, Ikeda H, Masukawa H and Sakurai H (2007) High photobiological hydrogen production activity of a Nostoc sp. PCC 7422 uptake hydrogenase-deficient mutant with high nitrogenase activity. Mar Biotechnol 9:101-112.

Zehr JP, Wyman M, Miller V, Duguay L and Capone DG (1993) Modification of the Fe protein of nitrogenase in natural populations of Trichodesmium thiebautii. Appl Environ Microb 59:669-676.

Zhao M-X, Jiang Y-L, He Y-X, Chen Y-F, Teng Y-B, Chen Y, Zhang C-C and Zhou C-Z (2010) Structural basis for the allosteric control of the global transcription factor NtcA by the nitrogen starvation signal 2-oxoglutarate. Proc Natl Acad Sci U S A 107:12487-12492.

Zheng L, White RH and Dean DR (1997) Purification of the Azotobacter vinelandii nif $\mathrm{V}$-encoded homocitrate synthase. J Bacteriol 179:5963-5966.

\section{Internet Resources}

Rambaut A (2009) FigTree v1. 3.1: Tree figure drawing tool. http://tree.bio.ed.ac.uk/software/figtree/

Associate Editor: Marcia Pinheiro Margis

License information: This is an open-access article distributed under the terms of the Creative Commons Attribution License (type CC-BY), which permits unrestricted use, distribution and reproduction in any medium, provided the original article is properly cited. 